\title{
The Effects of Recombinant Human Granulocyte-Macrophage Colony Stimulating Factor on the Neutrophil Respiratory Burst in the Term and Preterm Infant When Studied in Whole Blood
}

\author{
MERVYN S. JASWON, H. MARK JONES, AND DAVID C. LINCH \\ Departments of Haematology and Paediatrics, University College and Middlesex School of \\ Medicine, London, United Kingdom
}

\begin{tabular}{|c|c|}
\hline \multicolumn{2}{|c|}{ ABSTRACT } \\
\hline $\begin{array}{l}\text { To investigate further the susceptibility to infection of } \\
\text { newborn infants, particularly those born prematurely, we } \\
\text { have used a "whole blood" flow cytometric assay to com- } \\
\text { pare the respiratory burst activity in recombinant human } \\
\text { granulocyte-macrophage colony stimulating factor } \\
\text { "primed" neutrophils obtained from healthy adults, term } \\
\text { infants, and preterm newborn infants. The use of whole } \\
\text { blood avoids prior cell separation procedures that may cause } \\
\text { artifactual activation or priming. In healthy adults ( } n=21) \text {, } \\
\text { the bacterial cell wall peptide N-formyl-methionyl-leucyl- } \\
\text { phenylalanine induced little neutrophil respiratory burst ac- } \\
\text { tivity, suggesting that the circulating cell is relatively quies- } \\
\text { cent. Prior exposure to recombinant human granulocyte- } \\
\text { macrophage colony stimulating factor augmented the median } \\
\mathrm{N} \text {-formyl-methionyl-leucyl-phenylalanine response by } \\
425 \% \text {. In cord blood from full-term neonates ( } n=9) \text {, recom- } \\
\text { binant human granulocyte-macrophage colony stimulating } \\
\text { factor produced less enhancement of the N-formyl- } \\
\text { methionyl-leucyl-phenylalanine response ( } 345 \%) \text {, but the ab- } \\
\text { solute level of respiratory burst activity was at least as great } \\
\text { as in adults, suggesting that the neutrophils are fully func- } \\
\text { tional and partially primed after delivery. In preterm infants }\end{array}$ & $\begin{array}{l}\text { receiving intensive care }(n=10) \text {, the degree of priming was } \\
\text { similar to that in neutrophils from term infants }(344 \%) \text {, al- } \\
\text { though the absolute level of respiratory burst activity was } \\
\text { reduced }(p=0.0003) \text {. In response to stimulation with phor- } \\
\text { bol ester, } 73.5 \%(18-99 \%) \text { (median and range) of neutrophils } \\
\text { obtained from adults and } 77.6 \%(50-92 \%) \text { from term babies } \\
\text { exhibit respiratory burst activity detectable in the whole } \\
\text { blood assay. However, in neutrophils obtained from preterm } \\
\text { infants, there was a significant reduction in the phorbol } \\
\text { ester-induced respiratory burst, with only } 32.9 \%(21-61 \%) \\
\text { of cells responding ( } p=0.0129) \text {. (Pediatr Res 36: } \mathbf{6 2 3 - 6 2 7 ,} \\
\text { 1994) } \\
\text { Abbreviations } \\
\text { GM-CSF, granulocyte-macrophage colony stimulating } \\
\text { factor } \\
\text { rh, recombinant human } \\
\text { FMLP, N-formyl-methionyl-leucyl-phenylalanine } \\
\text { TPA, 12-O-tetradecanoylphorbol 13-acetate } \\
\text { NRB, neutrophil respiratory burst } \\
\text { MCF, mean cell fluorescence } \\
\mathbf{2}^{\prime} \mathbf{7}^{\prime} \text { DCFH-DA, } 2^{\prime} 7^{\prime} \text { dichlorofluoroscein diacetate }\end{array}$ \\
\hline
\end{tabular}

The newborn infant, particularly the preterm infant, has an increased susceptibility to infection, and this continues to be an important cause of morbidity and mortality in the neonatal period (1). This susceptibility is due to defects in both humoral and cellular immunity $(2,3)$.

The neutrophil plays a central role in host defense by its ability to migrate to a focus of infection, phagocytose microorganisms, and then destroy them. The killing of

Received December 1, 1992; accepted May 24, 1994.

Correspondence and reprint requests: Dr. M. S. Jaswon, Department of Paediatrics, Whittington Hospital, Highgate Hill, London N19 5NF, United Kingdom.

Supported in part by the Kay Kendall Leukaemia Trust. phagocytosed organisms is achieved principally through bactericidal oxygen metabolites, such as superoxide and hydrogen peroxide, which are produced by the NRB. The NRB is a metabolic pathway that is activated in vivo by phagocytosis of opsonized bacteria and in vitro by a variety of ligands such as the bacterial cell wall peptide FMLP that bind to surface receptors. The NRB can also be activated in vitro by the phorbol ester TPA, which directly activates protein kinase $C$, bypassing the early receptor-mediated signal transduction events. The activity of this pathway is increased by prior exposure of neutrophils to cytokines, such as GM-CSF or tumor necrosis factor- $\alpha$, which are released at sites of inflam- 
mation. These cytokines do not directly activate the NRB but augment its subsequent response. This process is referred to as priming, and it enables the neutrophil to mount an optimal response to infection.

Many studies have examined NRB activity in newborn infants in view of their increased susceptibility to infection, with conflicting conclusions; some data suggest that there is increased NRB activity and others that activity is decreased (4-6). More recently, the effects of priming of neutrophils obtained from newborn infants with rhGMCSF have also been investigated $(7,8)$. The majority of these studies have been on neutrophils obtained from term babies, with little data regarding the preterm infant, who is particularly at risk of infection. Furthermore, these studies have been performed using partially purified or isolated neutrophils, and it is well recognized that the purification procedures themselves may modulate surface receptor expression and cellular function, resulting in partial priming, thus making it difficult to determine exactly the effects of GM-CSF.

To simulate the in vivo situation more closely, we have developed a "whole blood" flow cytometric assay that allows priming and respiratory burst activity to be measured directly, in individual cells, without prior in vitro manipulation and purification procedures (9). Furthermore, this assay requires only small $(<0.5 \mathrm{~mL})$ samples of blood and is suitable for use in the neonatal period.

In this study, we have used a whole blood assay to examine the effects of preincubation with rhGM-CSF on the NRB in samples obtained from premature infants receiving intensive care, healthy term babies, and healthy adults.

\section{METHODS}

Materials. 2'7' DCFH-DA was obtained from Molecular Probes, Eugene, OR. FMLP and TPA were obtained from Sigma (Poole, Dorset, UK). DMSO and ethyl alcohol were obtained from BDH (Poole, Dorset, UK). Purified recombinant human GM-CSF was supplied by Hoechst/ Behringwerke (Hounslow, UK/Marburg, Germany). The assay kit for GM-CSF was obtained from Medgenix Diagnostics (Fleurus, Belgium). PBS and RPMI without sodium bicarbonate or phenol red were obtained from Gibco (Paisley, Scotland, UK).

The following stock solutions were prepared in DMSO, stored at $-20^{\circ} \mathrm{C}$, and diluted in PBS or RPMI on the day of the experiment: FMLP $(50 \mathrm{mg} / \mathrm{mL})$, TPA $(10 \mathrm{mg} / \mathrm{mL})$, and $2^{\prime} 7^{\prime}$ DCFH-DA. Fresh stock solutions of the latter were made each week. Lyophilized rhGM-CSF was dissolved in PBS and $10 \%$ FCS at $1 \mu \mathrm{g} / \mathrm{mL}$, stored at $-20^{\circ} \mathrm{C}$, and diluted in PBS on the day of the experiment.

Assay for intracellular oxidant production. Oxidant production was measured by an adaptation of the method of Bass et al. (10) for use in whole blood as previously described. Freshly drawn heparinized blood was incubated with $100 \mu \mathrm{mol} / \mathrm{L} 2^{\prime} 7^{\prime}$ DCFH-DA for $15 \mathrm{~min}$ at $37^{\circ} \mathrm{C}$. This was followed by incubation with $1 \mathrm{ng} / \mathrm{mL}$ rhGM-
$\mathrm{CSF}$ for $45 \mathrm{~min}$ at $37^{\circ} \mathrm{C}$, followed by the final agonist $\left(10^{-6} \mathrm{M}\right.$ FMLP for $5 \mathrm{~min}, 1 \mathrm{mg} / \mathrm{mL}$ of TPA for $\left.10 \mathrm{~min}\right)$. The reaction was stopped by placing the samples on ice; they then underwent red cell lysis and white cell fixation in preparation for analysis by flow cytometry, as previously described (9).

Flow cytometry analysis. An EPICS CD flow cytometer (Coulter, Luton, UK) with an argon laser emitting 200 $\mathrm{mW}$ at $488 \mathrm{nM}$ was used. Forward light scatter and right-angled light scatter were used to identify the granulocyte population and to exclude the remaining cells and cell debris from the analysis. Fluorescence was recorded using linear amplification with a photomultiplier tube. The flow cytometer was calibrated daily using standardized latex microspheres (Coulter). The response was expressed as the percentage of fluorescent neutrophils (\% positive cells), the MCF of those positive cells, and the product of these two values, the latter parameter providing an indication of the total respiratory burst activity in the whole neutrophil population. The gates for positive/ negative fluorescence were derived by visual examination of the histograms from unstimulated cells and set at $5 \%$. To eliminate differences in MCF between experiments due to changes in gain and voltage setting of the photomultiplier tube, all MCF results in stimulated cells were expressed as a percentage of unstimulated cells, with the latter being assigned a value of $100 \mathrm{U}$. To assess the variability of the assay, NRB activity was repeatedly measured in blood samples from particular individuals obtained over a period of time, and significant uniformity in their response was found. Thus, for example, in one individual in whom four samples were obtained over a period of $12 \mathrm{mo}$, the percentage increase in NRB activity in cells stimulated with FMLP was 223, 261, 212, and 276, with a coefficient of variation of $12.5 \%$.

GM-CSF assay. Plasma from all samples was stored at $-20^{\circ} \mathrm{C}$ until analyzed for the presence of human GMCSF. This was performed with an immunoenzymetric assay using three MAb directed against distinct epitopes of GM-CSF (Medgenix).

Blood samples. The study population comprised premature infants (22-32 wk gestation), term babies, and healthy laboratory personnel. The premature infants were all receiving neonatal intensive care, and the samples were obtained within the first $24 \mathrm{~h}$ after birth, either through indwelling arterial lines or venipuncture, at the same time that blood was being taken for clinical purposes (apart from one infant of $22 \mathrm{wk}$ gestation in whom blood was obtained from cord vessels after termination of pregnancy because of $\beta$-thalassemia major). Samples from normal term babies were obtained by venipuncture of placental or cord vessels, within $15 \mathrm{~min}$ of either vaginal delivery or cesarean section, and the purity of the specimen was assessed by the Kleihauer test. Control adult samples were obtained from healthy laboratory personnel. Approval for this study was granted by the local Committee on the Ethics of Clinical Investigations. 
Statistics. The median values for the groups of premature infants, term babies, and healthy adults were compared by the Mann-Whitney test. The comparison of paired primed and control cells within population groups was performed by the Wilcoxon signed-rank test.

\section{RESULTS}

Response of unprimed neutrophils from preterm and term babies and adults to FMLP. Addition of FMLP $10^{-6} \mathrm{M}$ to unprimed blood from premature infants $(n=10)$ and adults $(n=21)$ stimulated only minor NRB activity. However, in blood from term infants $(n=9)$, there was a significant increase in NRB activity that was mainly due to recruitment of a higher percentage of responding cells. Five percent $(2-12 \%)$ (median and range) of unstimulated neutrophils were deemed to be fluorescent, and addition of FMLP caused an increase in the number of fluorescent cells to $10 \%(2-57 \%)$ in adults, $11.2 \%(7-29 \%)$ in premature infants, and $28.6 \%$ (5-83\%) in term infants (Table 1). In blood from term infants, there was also an increase in the MCF of the positive cells $(p=0.01)$.

Response of primed neutrophils from preterm and term babies and adults to FMLP. Prior incubation of whole blood with rhGM-CSF resulted in significant enhancement of the response to $10^{-6} \mathrm{M}$ FMLP in samples from both premature and term infants. This enhancement was principally due to an increase in the percentage of responding cells from $11.2 \%$ (7-29\%) to $38.3 \%$ (8-64\%) ( $p$ $=0.006)$ in premature infants and from $28.6 \%(5-83 \%)$ to $69.3 \%(44-95 \%)(p=0.004)$ in term babies. There was a small increase in MCF, which was significant in samples from newborn infants and adults $(p=0.005)$ (Table 1$)$. The enhancement of NRB activity in term babies with rhGM-CSF was less than that seen in healthy adults ( 345 versus $425 \%$ ), although the absolute level of NRB activity reached was at least as great. In premature infants, the degree of priming was similar to that in term babies (344 versus $345 \%$ ), although the absolute level of NRB activity attained was lower.
Response of unprimed neutrophils from preterm and term babies and adults to TPA. Addition of $1 \mu \mathrm{g} / \mathrm{L}$ TPA to unprimed blood from term infants $(n=9)$ and adults $(n=$ 13) caused marked NRB activity, with $73.5 \%(18-99 \%)$ of neutrophils from adults and $77.6 \%$ (50-92\%) from term infants showing a positive response. However, in samples obtained from preterm infants $(n=10)$, there was a significant reduction in NRB activity compared with adults $(p=0.0129)$, which was mainly due to a reduction in the number of positive cells, with only $32.9 \%(21-61 \%)$ of neutrophils responding (Table 2).

Response of primed neutrophils from preterm and term babies and adults to TPA. Prior incubation of whole blood from adults and term infants with rhGM-CSF resulted in significant enhancement of the response to TPA, although the components of the response varied between the different populations studied. In adults, the priming seen with TPA was mainly due to an increase in the MCF of the positive cells, whereas in term infants, although an increase in MCF was also seen, statistical significance ( $p$ $=0.006$ ) was only achieved regarding the small increase in the number of positive cells (77.6 versus $86.8 \%$.) Neutrophils obtained from preterm infants showed a modest but significant priming effect, which was due to an increase in both the number of responding cells ( 32.9 versus $47.7 \%$ ) and the MCF of these cells, but only reached statistical significance in the latter parameter $(p=0.005)$ (Table 2).

GM-CSF assay. GM-CSF was not detected in any of the samples studied. The lower limit of detection in the assay used was $30 \mathrm{pg} / \mathrm{mL}$ for both recombinant (Escherichia coli, yeast) and mammalian cell-produced GM-CSF.

\section{DISCUSSION}

In this study, we have shown in a whole blood assay that both term and preterm infants have the ability to show increased NRB activity after preincubation with rhGM-CSF. This agrees with the findings of Frenck et al. (7) and Cairo et al. (8), who looked at purified neutrophils

Table 1. Effect of preincubation with rhGM-CSF on FMLP-induced neutrophil respiratory burst in healthy adults and term and preterm newborn infants*

\begin{tabular}{|c|c|c|c|c|c|c|c|c|}
\hline & \multicolumn{2}{|c|}{ Adult } & \multicolumn{2}{|c|}{ Term } & \multicolumn{2}{|c|}{ Preterm } & \multicolumn{2}{|c|}{ Adult $v s$ term } \\
\hline & $\begin{array}{c}\text {-rhGM- } \\
\text { CSF }\end{array}$ & $\begin{array}{l}+ \text { rhGM- } \\
\text { CSF }\end{array}$ & $\begin{array}{c}-\mathrm{rhGM}- \\
\mathrm{CSF}\end{array}$ & $\begin{array}{c}+ \text { rhGM- } \\
\text { CSF }\end{array}$ & $\begin{array}{c}\text {-rhGM- } \\
\text { CSF }\end{array}$ & $\begin{array}{c}+ \text { rhGM- } \\
\text { CSF }\end{array}$ & $\begin{array}{c}-\mathrm{rhGM}- \\
\mathrm{CSF}\end{array}$ & $\begin{array}{c}\text { +rhGM- } \\
\text { CSF }\end{array}$ \\
\hline \multirow[t]{3}{*}{$\%$ Positive cells } & 10 & 43 & 28.6 & 69.3 & 1.2 & 38.3 & & \\
\hline & $2-57$ & $5-100$ & $5-83$ & $44-95$ & $7-29$ & $8-64$ & & \\
\hline & \multicolumn{2}{|c|}{$p<0.0001$} & \multicolumn{2}{|c|}{$p=0.004$} & \multicolumn{2}{|c|}{$p=0.006$} & $p=0.0049$ & $p=0.0231$ \\
\hline \multirow{3}{*}{$\mathrm{MCF}$} & 103 & 120 & 135 & 184 & 106 & 122 & & \\
\hline & $80-143$ & $83-367$ & $95-412$ & $114-455$ & $94-122$ & $94-159$ & & \\
\hline & \multicolumn{2}{|c|}{$p<0.0005$} & \multicolumn{2}{|c|}{$p=0.005$} & \multicolumn{2}{|c|}{$p=0.005$} & $p=0.0298$ & $p=0.049$ \\
\hline \multirow[t]{2}{*}{ Product } & 1089 & 5375 & 3393 & 11730 & 1127 & 4768 & & \\
\hline & \multicolumn{2}{|c|}{$p<0.0001$} & \multicolumn{2}{|c|}{$p=0.004$} & $\begin{array}{r}698-3461 \\
p=\end{array}$ & $\begin{array}{l}844-7257 \\
006\end{array}$ & $p=0.0026$ & $p=0.0155$ \\
\hline
\end{tabular}

${ }^{*}$ Whole blood was first incubated for $45 \mathrm{~min}$ at $37^{\circ} \mathrm{C}$ with either $1 \mathrm{ng} / \mathrm{mL}$ rhGM-CSF or diluent and then with $10^{-6} \mathrm{M}$ FMLP for $5 \mathrm{~min}$ at $37^{\circ} \mathrm{C}$. The data given are the medians and ranges for the percentage of positive (fluorescent) cells, the MCF of the positive cells, and the product of these two parameters. The baseline values for unstimulated cells are as follows: $\%$ positive cells, $5.0 \%(2-12 \%)$; MCF, 100 . 
Table 2. Effect of preincubation with rhGM-CSF on TPA $(1 \mu \mathrm{g} / \mathrm{mL})$-induced neutrophil respiratory burst in healthy adults and term and preterm newborn infants*

\begin{tabular}{|c|c|c|c|c|c|c|c|c|}
\hline & \multicolumn{2}{|c|}{ Adult } & \multicolumn{2}{|c|}{ Term } & \multicolumn{2}{|c|}{ Preterm } & \multicolumn{2}{|c|}{ Adult $v s$ preterm } \\
\hline & $\begin{array}{c}- \text { rhGM- } \\
\text { CSF }\end{array}$ & $\begin{array}{c}+ \text { rhGM- } \\
\text { CSF }\end{array}$ & $\begin{array}{c}\text {-rhGM- } \\
\text { CSF }\end{array}$ & $\begin{array}{c}+ \text { rhGM- } \\
\text { CSF }\end{array}$ & $\begin{array}{l}- \text { rhGM- } \\
\text { CSF }\end{array}$ & $\begin{array}{c}\text { +rhGM- } \\
\text { CSF }\end{array}$ & $\begin{array}{c}- \text { rhGM- } \\
\text { CSF }\end{array}$ & $\begin{array}{c}+ \text { rhGM- } \\
\text { CSF }\end{array}$ \\
\hline \multirow[t]{3}{*}{$\%$ Positive cells } & 73.5 & 83 & 77.6 & 86.8 & 32.9 & 47.2 & & \\
\hline & $18-99$ & $35-100$ & $50-92$ & $70-98$ & $21-61$ & $23-74$ & & \\
\hline & \multicolumn{2}{|c|}{$p=0.027$} & \multicolumn{2}{|c|}{$p=0.006$} & \multicolumn{2}{|c|}{$p=0.033$} & $p=0.0129$ & $p=0.0105$ \\
\hline \multirow[t]{3}{*}{$\mathrm{MCF}$} & 138 & 192 & 229 & 226 & 113 & 128 & & \\
\hline & $92-593$ & $108-750$ & $145-292$ & $174-485$ & 102-195 & $101-203$ & & \\
\hline & \multicolumn{2}{|c|}{$p=0.002$} & \multicolumn{2}{|c|}{$p=0.025$} & \multicolumn{2}{|c|}{$p=0.005$} & $p=\mathrm{NS}$ & $p=\mathrm{NS}$ \\
\hline \multirow[t]{3}{*}{ Product } & 11506 & 16311 & 18111 & 19262 & 4497 & 6203 & & \\
\hline & $2286-52184$ & $3780-65250$ & $1146-26756$ & $13339-47336$ & $2437-9647$ & $2300-12307$ & & \\
\hline & \multicolumn{2}{|c|}{$p=0.001$} & \multicolumn{2}{|c|}{$p=0.009$} & \multicolumn{2}{|c|}{$p=0.019$} & $p=0.0276$ & $p=0.0069$ \\
\hline
\end{tabular}

* Incubation with rhGM-CSF was as described in Table 1. The data are as expressed in Table 1 , as are the values for unstimulated cells.

obtained from the cord blood of term infants. The ability to prime with GM-CSF partly depends on the presence of the relevant surface receptors, and these were recently demonstrated by Cairo et al. (11) in neutrophils from newborn term babies. In a promyelocytic cell line (HL60 ) in which differentiation has been induced by DMSO, the ability to prime is present as soon as respiratory burst activity can be detected (12), and from our data this also appears to be the case in human development.

In the term babies studied, there was an increased degree of NRB activity even without preincubation with rhGM-CSF, and this implied that their neutrophils were already partially primed. Examination of the mode of delivery indicated that the more stressful the delivery, the greater the degree of priming (although the small number of babies studied did not allow statistical analysis); the greatest NRB activity seen in neutrophils was obtained from an infant delivered vaginally after a 4-h second stage, whereas the least NRB activity was observed in an infant delivered by elective cesarean section. The reason for this priming effect is unclear. Using an ELISA with a highly specific MAb directed against GMCSF, we were unable to detect circulating GM-CSF in any of the infants studied. This differs from the findings of Laver et al. (13), who, using a growth assay of a GMCSF-dependent cell line, found increased levels of GMCSF in the cord blood of term babies. Although neutralizing antibodies were used to ascertain the specificity of the assay, there was $11 \%$ residual activity, implying the presence of other growth factors in addition to GM-CSF.

The neutrophils from preterm infants undergoing neonatal intensive care showed reduced NRB activity compared with adults when stimulated with TPA; this reduction was principally due to a smaller percentage of responsive cells. To ascertain that the reduced activity was due to the prematurity of the infants from whom the samples were obtained, rather than an effect of the "stress" of intensive care, samples were obtained from two preterm infants at the time of delivery, both of whom showed a reduced response to TPA of the same degree as seen in the other preterm infants. The FMLP-induced response in the preterm infants was also reduced and was approximately $50 \%$ of the levels obtained in the adult, although this difference did not reach statistical significance. The reason for the reduced NRB activity seen in preterm infants is unclear. Examination of blood films of the samples studied showed the presence of morphologically mature neutrophils, with a lobular nucleus and granular cytoplasm. Dore et al. (14) found reduced NRB activity in neutrophils obtained from preterm calves and found that this was due to diminished amounts of membrane-bound NADPH-oxidase. Our findings imply that the neutrophil population in preterm infants is heterogeneous, with only a relatively small proportion of cells having a sufficiently developed oxidase system to show a positive response in the assay used here.

In a whole blood assay, it must be acknowledged that one cannot exclude indirect effects from accessory cells; however, this method allows one to examine neutrophil function in conditions as near as possible to their natural milieu.

The method of obtaining samples varied between the groups studied (because of ethical and logistical considerations), but this is unlikely to account for the observed differences because sample collection was consistently without "stress."

The functional significance of these data is that reduced NRB activity may be implicated in the increased susceptibility of the preterm infant to infection. However, the demonstration in this study that neutrophils from both term and preterm infants possess the capability in vitro to prime their NRB to show increased activity indicates that administering rhGM-CSF to enhance neutrophil function, particularly to the susceptible preterm infant, is a therapeutic possibility. This is particularly appropriate in view of the increasing evidence that cytokine production is impaired in the neonate, and studies indicating deficiencies of growth factors have recently been published (15-17).

Acknowledgments. The authors thank Professor E. O. R. Reynolds for permission to study infants under his care and R. Pearse for statistical advice. 


\section{REFERENCES}

1. Siegel JD, McCracken GH 1981 Sepsis neonatorum. N Engl J Med 304:642647

2. Wilson C 1986 Immunologic basis for increased susceptibility of the neonate to infection. J Pediatr 108:1-12

3. Hill HR 1987 Biochemical, structural, and functional abnormalities of polymorphonuclear leukocytes in the neonate. Pediatr Res 22:375-382

4. Miller ME 1979 Phagocyte function in the neonate: selected aspects. Pediatrics 65(suppl):709-712

5. Strauss RG, Snyder EL 1983 Activation and activity of the superoxidegenerating system of neutrophils from human infants. Pediatr Res 17:662-664

6. Ambruso DR, Stork LC, Gibson BE, Thurman GW 1987 Increased activity of the respiratory burst in cord blood neutrophils: kinetics of the NADPH oxidase enzyme system in subcellular fractions. Pediatr Res 21:205-209

7. Frenck Jr RW, Buescher ES, Vadhan-Raj S 1989 The effects of recombinant human granulocyte-macrophage colony stimulating factor on in vitro cord blood granulocyte function. Pediatr Res 26:43-48

8. Cairo MS, van de Ven C, Toy C, Mauss D, Sender L 1989 Recombinant human granulocyte-macrophage colony-stimulating factor primes neonatal granulocytes for enhanced oxidative metabolism and chemotaxis. Pediatr Res 26:395-399

9. Jaswon MS, Khwaja A, Roberts PJ, Jones HM, Linch DC 1990 The effects of rhGM-CSF on the neutrophil respiratory burst when studied in whole blood. Br J Haematol 75:181-187
10. Bass DA, Parce JW, DeChatelet LR, Szejda P, Seeds MC, Thomas M 1983 Flow cytometric studies of oxidative product formation by neutrophils: a graded response to membrane stimulation. J Immunol 130:1910-1917

11. Cairo MS, Suen Y, Knoppel E, van de Ven C, Nguyen A, Sender L 1991 Decreased stimulated GM-CSF production and GM-CSF gene expression but normal numbers of GM-CSF receptors in human term newborns compared with adults. Pediatr Res 30:362-367

12. Roberts PJ, Lie AKW, Jones HM, Khwaja A, Yong K, Bybee A, Thomas NSB, Linch DC 1990 Differentiation linked effects of GM-CSF: studies in HL-60 cells. Blood 76(suppl 1):192a(abstr)

13. Laver J, Duncan E, Abboud M, Gasparetto C, Sahdev I, Warren D, Bussel J, Auld P, O'Reilly RJ, Moore MAS 1990 High levels of granulocyte and granulocyte-macrophage colony-stimulating factors in cord blood of normal full-term neonates. J Pediatr 116:627-632

14. Dore M, Slauson DO, Neilsen NR 1990 Membrane NADPH oxidase activity and cell size in bovine neonatal and adult neutrophils. Pediatr Res 28:327-331

15. Wilson CB, Lewis DB 1990 Basis and implications of selectively diminished cytokine production in neonatal susceptibility to infection. Rev Infect Dis 12(suppl 4):410-420

16. Cairo MS, Suen Y, Knoppel E, van de Ven C, Nguyen A, Sender L 1991 Decreased stimulated GM-CSF gene expression but normal numbers of GMCSF receptors in human term newborns compared with adults. Pediatr Res 30:362-367

17. Schibler KR, Liechty KW, White WL, Rothstein G, Christensen RD 1992 Defective production of IL- 6 by monocytes: a possible mechanism underlying several host defense deficiencies of neonates. Pediatr Res 31:18-21 